\title{
NOVOS MÉTODOS PARA FILTRAGEM DE DADOS SÍSMICOS DE REFLEXÃO
}

\author{
Paulo Espinheira Menezes de Melo \\ Orientador: Dr. Milton José Porsani (UFBA) \\ 79 p. - Tese (Doutorado) - Defesa 23.02.2007
}

\begin{abstract}
RESUMO. A busca no aumento da resolução e na melhoria da qualidade das imagens sísmicas tem motivado o desenvolvimento de novos métodos de filtragem para o processamento de dados sísmicos. Neste trabalho apresentamos dois novos métodos para o processamento de dados sísmicos de reflexão. Um método de deconvolução iterativa do pulso sísmico e outro método de filtragem para atenuação do groundroll. 0 primeiro é 0 método de deconvolução iterativa, diferente do convencional de Wiener-Levinson, que minimizar a norma $L_{2}$ do traço deconvolvido, utiliza filtro de comprimento variável, causal e anti-causal, combinado com a norma $L_{p}$ variável a cada iteração. Exemplos utilizando dados sintéticos demonstram a superioridade do método proposto comparado com o método convencional de deconvolução, conseguindo comprimir pulsos com caráter de fase mínima, máxima ou mista a um impulso, recuperando a função refletividade, mesmo quando esta não é perfeitamente aleatória. 0 método foi aplicado em dados sintéticos e sobre duas linhas da foz do rio Amazonas, pós-empilhadas, e os resultados atestam sua robustez no aumento da resolução temporal da seção sísmica empilhada. 0 segundo método é a filtragem direcional 2D para atenuação do groundroll. Este baseia-se na aplicação de um filtro bidimensional (2D) para obtenção da derivada temporal dos sismogramas. 0 filtro é aplicado sobre famílias de traços corrigidos do sobretempo normal (NMO). Este filtro possui a propriedade de revelar as reflexões horizontais ou subhorizontais e atenuar os eventos lineares com direções verticais ou subverticais. Um conjunto regular de amostras da vizinhança de cada ponto $(t, x)$ do sismograma, é utilizado para obtenção da derivada. 0 operador 2D de derivada é obtido tomando a diferença entre os valores interpolados, calculados na vizinhança positiva e negativa da posição desejada. Este é calculado uma única vez e aplicado, na forma de convolução, à matriz de dados que representa os sismogramas. Resultados numéricos usando dados sísmicos reais, pré-empilhados, da bacia sedimentar do Tacutu, mostram que o método proposto é eficaz, conseguindo aumentar a resolução temporal e revelar as reflexões subjacentes mascaradas pelo groundroll. 0 novo método de filtragem fornece resultados de qualidade superior, quando comparados com o método convencional de filtragem FK.
\end{abstract}

ABSTRACT. The importance of the seismic resolution, and of the quality of the seismic images to the industry of petroleum, has motivated the development of new filtering techniques for processing of the seismic reflection data. In this thesis we present two new filtering methods to improve the signal to noise ratio of the seismic sections. The first filtering method address the wavelet deconvolution problem. Unlike the conventional WienerLevinson approach which uses causal filter and $L_{2}$ norm, the proposed method is iterative and uses causal and anti-causal filters, combined with variable norm, during each iteration. Numerical results using synthetic seismic data demonstrates its ability to overcome some limitations of the conventional Wiener-Levinson method, providing good results even when the wavelet is not minimum-phase or the reflectivity series is not a random process. Numerical examples using post-stack marine seismic reflection data, demonstrates the efficacy of the new iterative wavelet deconvolution method. The second filtering method address the groundroll attenuation problem. The groundroll, present in land seismic data, is responsible for a significant reduction in the signal-to-noise ratio. We present a new filtering method for the groundroll attenuation. A 2D normal derivative filter is applied to families of traces, corrected from the normal moveout. This filtering approach can reveal horizontal or sub-horizontal reflections while vertical or subvertical events are attenuated. A regular, $N \times N$, set of samples, around each data sample of the seismogram, are used to estimate the normal derivative at each desired position. The normal derivative is computed by taking the difference between the interpolated values, calculated in both the positive and negative neighborhood of the desired position. The $2 \mathrm{D}$ derivative operator is convolved with the data matrix corresponding to the seismograms. Numerical results, using land seismic data, shows that the proposed method is effective to reveal reflections masked by the groundroll. The new filtering approach allow us to obtain post-stacked section of outstanding quality, when compared to the conventional FK filtering method. 